Al-Manhaj: Jurnal Hukum dan Pranata Sosial Islam

Vol. : : 3 (1), 2021, 1-34

P-ISSN : 2686-1607

E-ISSN : 2686-4819

\title{
ANALISIS PENOLAKAN ISBAT NIKAH PERSPEKTIF STUDI HUKUM KRITIS
}

\author{
Rika Nur Laili, Lukman Santoso \\ Institut Agama Islam Negeri Ponorogo \\ email: rikanurlaili1997@gmail.com, lukmansantoso4@gmail.com
}

Abstract: This research is based on the problem of isbat nikah request which was rejected by the Ponorogo Religious Court through a determination with case number 402 / Pdt.P /2018/PA.Po. The purpose of this research focuses on the study of the legal interpretation paradigm of judges for rejection of marriage wives which is then analyzed based on the perspective of critical legal studies. This type of research is normative legal research which includes library research with descriptive analysis method. While the data collection technique is a documentation analysis study. The findings of this study: first, the legal interpretation used by the panel of judges in this determination is a systematic interpretation. Meanwhile, the method used by the panel of judges in this case used grammatical interpretation. This can be seen from the basis of legal considerations that the judge rejected the request for marriage is the hadith of the Prophet Muhammad regarding the existence of a marriage guardian as narrated by Ibn Hibban, Article 20 and Article $23 \mathrm{KHI}$, Article 1 paragraph (2) PMA No. 30 of 2005, Article 2 paragraph (1) Law No. 1 of 1974 concerning Marriage. Second, from the perspective of critical legal studies, the panel of judges uses a posivistic paradigm, namely not making any legal breakthroughs. This happens because the law is deemed capable of answering cases, the judge then does not grant marriage requests in order to prioritize the value of legal certainty over the value of justice and the value of benefit. This judge's decision contradicts Gustav 
Radbruch's standard priority theory, which is the first priority order of justice, second benefit and third legal certainty.

Keywords: marriage isbat, siri marriage, wali muhakkam, critical legal studies.

Abstrak: Penelitian ini berangkat dari problem permohonan isbat nikah karena menikah siri yang ditolak oleh Pengadilan Agama Ponorogo melalui Penetapan dengan nomor perkara 402/Pdt.P /2018/PA.Po. Tujuan penelitian ini memfokuskan kajian pada paradigma interpretasi hukum hakim atas penolakan isbat nikah yang kemudian dianalisis berdasarkan perspektif studi hukum kritis. Jenis penelitian yang digunakan adalah penelitian hukum normatif yang termasuk studi kepustakaan (library research) dengan metode analisis deskriptif. Sedangkan teknik pengumpulan data adalah studi analisis dokumentasi. Temuan dari penelitian ini: pertama, Interpretasi hukum yang digunakan majelis hakim dalam penetapan ini adalah Interpretasi sistematis. Sedangkan metode yang digunakan majelis hakim dalam perkara ini menggunakan interpretasi gramatikal. Hal ini dapat dilihat dari dasar pertimbangan hukum hakim menolak permohonan isbat nikah adalah hadis Rasulullah tentang harus adanya wali nikah yang diriwayatkan oleh Ibnu Hibban, Pasal 20 dan Pasal 23 KHI, Pasal 1 ayat (2) PMA No 30 Tahun 2005, Pasal 2 ayat (1) UU No 1 Tahun 1974 Tentang Perkawinan. Kedua, Dilihat dari perspektif studi hukum kritis, majelis hakim menggunakan paradigma posivistik yaitu tidak melakukan terobosan hukum. Hal ini terjadi karena undang-undang dianggap telah mampu menjawab kasus, hakim kemudian tidak mengabulkan permohonan isbat nikah demi mendahulukan nilai kepastian hukum daripada nilai keadilan dan nilai kemanfaatan. Keputusan hakim ini berseberangan dengan teori prioritas baku Gustav Radbruch yang dengan urutan prioritas pertama keadilan, kedua manfaat dan ketiga kepastian hukum.

Kata Kunci: isbat nikah, nikah siri, wali muhakkam, studi hukum kritis. 


\section{PENDAHULUAN}

Dalam menjalankan pranata kehidupan, untuk membentuk keluarga, manusia membutuhkan institusi perkawinan yang sah sesuai dengan norma agama dan tata aturan yang diberlakukan oleh negara. Perkawinan harus memenuhi rukun yang terdiri dari calon mempelai pria, calon mempelai wanita, wali nikah, dua orang saksi, dan akad (ijab dan kabul). ${ }^{1}$ Saksi pun harus memenuhi syarat. $^{2}$

Wali nikah merupakan rukun perkawinan yang menentukan keabsahan suatu perkawinan. ${ }^{3}$ Dalam konteks ini, menarik mencermati kasus yang terjadi di Ponorogo terkait perkawinan menggunakan wali nikah selain wali nasab dan wali hakim (penguasa atau orang yang diangkat oleh pemerintah). Wali tersebut adalah seorang laki-laki yang diangkat oleh calon Istri/keluarga calon istri atau disebut dengan wali muhakkam. ${ }^{4}$

Perkawinan semacam ini merupakan perkawinan yang tidak tercatat, sehingga selain berpotensi merugikan hak sipil perempuan juga merugikan hak perdata anak. Implikasinya harus

1 Pasal 14 Kompilasi Hukum Islam.

2 Hilman Hadikusuma, Hukum Perkawinan Indonesia Menurut: Perundangan, Hukum Hukum Agama (Bandung: CV. Mandar Maju, 2007), 6. Lihat pula Nur Lailatul Musyafa'ah, "Studi Hukum Perkawinan Islam Di Indonesia Perspektif Gender," aL-Hukama' 4, no. 2 (2014): 409-430.

3 Secara administratif, jika ada calon mempelai wanita yang tidak mempunya wali maka yang menjadi wali nikahnya adalah kepala KUA yang ditunjuk oleh Menteri Agama. Lihat Dian Mustika, "Pencatatan Perkawinan dalam Undang-undang Hukum Keluarga di Dunia Islam," Inovatif: Jurnal Ilmu Hukum 4, no. 5 (2011).

4 Abdul Kadir Syukur, "Pernikahan dengan Wali Muhakkam (Studi Tentang Implikasi dan Persepsi Ulama di Kota Banjarmasin)," Syariah: Jurnal Hukum dan Pemikiran 14, no. 1 (2014). 
mengajukan permohonan isbat nikah ke Pengadilan Agama. ${ }^{5}$ Kasus tersebut kemudian diajukan permohonan di Pengadilan Agama Ponorogo dengan nomor perkara 402/Pdt.P/2018/PA.Po. ${ }^{6}$ Pada prinsipnya permohonan isbat nikah dapat diajukan dengan tujuan pengesahan perkawinan dan perkara lainnya dan untuk memenuhi pencatatan perkawinan dan pencatatan kelahiran. ${ }^{7}$ Salah satu fungsi permohonan isbat nikah adalah untuk pengurusan akta kelahiran dari perkawinan sirri. ${ }^{8}$

Terdapat beberapa faktor penyebab yang mempengaruhi pasangan suami istri melakukan perkawinan sirri dan tidak tercatat, antara lain: (1) kesadaran hukum yang masih rendah; masyarakat masih banyak yang kurang mengetahui pentingnya pencatatan perkawinan, terutama bagi masyarakat pedesaan; (2) adat istiadat, dimana sudah turun temurun sejak dahulu orang tuanya juga tidak dicatatkan perkawinannya; (3) sebagian kecil ekonomi (tidak mampu/tidak punya biaya) dan (4) kyai/tokoh agama lokal kurang mendukung program pemerintah dalam pelaksanaan UU Perkawinan; (5) keinginan berpoligami namun

5 Tim Penyusun, Kompilasi Hukum Islam (Bandung: Nuansa Aulia, 2015), 3. Lihat pula Trusto Subekti, "Sahnya Perkawinan Menurut Undang-undang Nomor 1 Tahun 1974 Tentang Perkawinan Ditinjau dari Hukum Perjanjian," Jurnal Dinamika Hukum 10, no. 3 (2010): 329-338.

6 Dokumen Penetapan Pengadilan Agama Ponorogo Perkara Nomor:402/Pdt.P/2018/PA.PO., 7.

7 Pasal 1, Peraturan Mahkamah Agung Nomor 1 Tahun 2015.

8 Mukhtaruddin Bahrum, "Legalisasi Nikah Sirri Melalui Isbat Nikah Menurut Kompilasi Hukum Islam," Jurnal Diskursus Islam 1, no. 2 (August 29, 2013): 221. 
tidak mendapat izin dari istri pertama: (6) tidak ingin repot-repot mengurus surat-surat persyaratan perkawinan. ${ }^{9}$

Menurut hukum Islam, melakukan perkawinan secara sirri adalah sah, jika memenuhi syarat rukun perkawinan. Namun dilihat dari aspek peraturan perundang-undangan perkawinan model ini belum memiliki landasan hukum lengkap dikarenakan belum dicatatkan. ${ }^{10}$ Sehingga akan timbul akibat hukum antara lain: Pertama, perkawinan dianggap tidak sah. Kedua, anak hanya mempunyai hubungan perdata dengan ibu dan keluarga ibu. ${ }^{11}$

Pada kasus penetapan penolakan isbat nikah ini perkawinannya dianggap tidak sah karena tidak memiliki kekuatan hukum dan menimbulkan dampak negatif. Dampak negatif tersebut antara lain, pertama, istri tidak berhak menuntut nafkah dan harta bersama. Kedua, anak yang terlahir dari perkawinan sirri tersebut hanya mempunyai hubungan perdata dengan ibunya saja dan tidak memiliki hak waris dari ayahnya.

Sedangkan putusan hakim idealnya yang diharapkan masyarakat pencari keadilan adalah mampu menerapkan asas kepastian hukum, kemanfaatan dan keadilan. ${ }^{12}$ Dalam tataran ideal, hakim sebenarnya dimungkinkan memiliki koridor penafsiran hukum

${ }^{9}$ Balitbang Kemenag, Menelusuri Makna di Balik FenomenaPerkawinan di Bawah Umur dan Perkawinan Tidak Tercatat (Jakarta: Puslitbang Kehidupan Keagamaan, 2013).273-274.

10 Abdul Ghofur Anshori, Hukum Perkawinan Islam (Yogyakarta: UII Press, 2011). 211.

${ }^{11}$ Endang Ali Ma'sum, Kepastian Hukum Itsbat Nikah, disampaikan dalam Forum Diskusi Penelitian Oleh Balitbang Diklat Kumdil MA RI, Banten, 15 Mei 2012, 3. Lihat pula Bahrum, "Legalisasi Nikah Sirri Melalui Isbat Nikah Menurut Kompilasi Hukum Islam."

12 Supandriyo, Asas Kebebasan Hakim dalam Penjatuhan Pidana (Yogyakarta: Arti Bumi Intaran, 2019). 82 
yang lebih luas dan putusan pun sejatinya dipengaruhi oleh paradigma hakim tersebut. Sehingga dalam konteks putusan hukum hakim, dari sisi paradigma dapat diketahui bahwa hakim terbagi menjadi dua, yaitu paradigma positivistik dan paradigma diluar positivistik. ${ }^{13}$

Dalam perspektif studi hukum kritis (Critical Legal Studies; $C L S$ ) terbentuknya hukum dipengaruhi oleh berbagai faktor nonhukum seperti: kepentingan ekonomi, ras, gender, atau politik. Pembentukan hukum senantiasa mengandaikan interaksi dan negosiasi berbagai kelompok masyarakat. Akibatnya analisa hukum doktrinal hanya akan mengisolasi hukum dari konteks sosial-politiknya sehingga membuat hukum tidak bisa mengatasi berbagai masalah sosial politik: diskriminasi ras, gender, agama, atau kelas. ${ }^{14}$

CLS menolak anggapan tentang netralitas obyektivitas hukum sebagaimana yang diyakini Positivisme Hukum. Sebab menurut Roberto M. Unger, setiap metode hukum tertentu akan menghasilkan pilihan hukum tertentu. Dengan kata lain paradigma hukum yang dipilih oleh hakim akan menghasilkan keputusan hukum yang tertentu pula. Setiap pembuatan hukum dengan sendirinya mencerminkan nilai-nilai sosial-politik tertentu.

Berangkat dari fenomena tersebut, peneltian ini akan fokus menelaah topik tentang penolakan isbat nikah terkait penetapan

13 Widodo Dwi Putro, "Tinjauan Kritis-Filosofis Terhadap Paradigma Positivisme Hukum" (Disertasi, Jakarta, Universitas Indonesia, 2011). 3

14 Putro., 134. Lihat pula Ghufron Maksum, "Telaah Kritis Terhadap Praktik Perkawinan di Bawah Tangan di Indonesia," Kordinat: Jurnal Komunikasi Antar Perguruan Tinggi Agama Islam 16, no. 1 (2017): 63-86. 
pengadilan dalam kasus Nomor: 402/Pdt.P/2018/PA. Po. Maka penelitian ini termasuk dalam penelitian hukum normatif menggunakan library research. Adapun data yang digunakan terdiri dari bahan hukum primer, sekunder dan tersier. ${ }^{15}$ Urgensi peneliti menggunakan jenis penelitian ini karena yang diteliti merupakan dokumen Penetapan Pengadilan Agama Ponorogo.

Penelitian tentang wali nikah dan pernikahan siri menggunakan wali muhakkam yang kemudian diajukan isbat nikah, telah dilakukan beberapa peneliti diantaranya oleh Zuni Ayu Pratiwi, ${ }^{16}$ Nur Halimah, ${ }^{17}$ Andi Rishadi, ${ }^{18}$ dan Alwi Sihab, ${ }^{19}$ namun dari penelitian tersebut hanya membahas seputar konsep nikah sirri, implementasi dan implikasi permohonan isbat nikah dan tidak membahas terkait kasus penolakannya secara komprehensif.

Berdasarkan pemaparan di atas, penelitian ini berbeda dengan penelitian-penilitian yang pernah dilakukan, karena peniltian ini fokus pada interpretasi hukum hakim atas penolakan

15 Soerjono Soekanto, Pengantar Penelitian Hukum (Jakarta: UI Press, 2010). 52. Lihat pula Made Pasek Diantha, Metodologi Penelitian Hukum Normatif dalam Justifikasi Teori Hukum (Jakarta: Prenada Media Grup, 2017). 141.

16 Zuni Ayu Pratiwi, "Analisis Yuridis Terhadap Isbat Nikah Karena Pernikahan Sirri Oleh Wali Muhakkam dalam Penetapan Pengadilan Agama Bangkalan No. 720/Pdt.P/2017/PA.Bkl" (Skripsi, Surabaya, UIN Sunan Ampel, 2018). 10.

17 Nur Halimah,"Analisis Terhadap Penolakan Permohonan Isbat Nikah dan Asal-Usul Anak (Studi Penetapan Pengadilan Agama Blora Nomor: 0056/Pdt.P/2015/PA.Bla),"Skripsi (Semarang: UIN Semarang, 2016).

18 Andi Rishadi, "Praktik Pernikahan Sirri dengan Menggunakan Wali Muhakkam di Desa Karang Rejo Kecamatan Jorong Kabupaten Tanah Laut," Skripsi (Banjarmasin:UIN Banjarmasin, 2018 ), 3.

19 Alwi Sihab, "Peran Kiai Sebagai Wali Muhakkam" (Skripsi, Malang, UIN Maliki, 2013). 3. 
isbat nikah karena pernikahan siri menggunakan wali muhakkam dan analisis Critical Legal Studies atas putusan tersebut.

\section{PARADIGMA HAKIM DALAM MEMUTUS PERKARA}

Hakim memiliki mekanisme yang berbeda-beda dalam memutus suatu perkara. Perbedaan latar belakang pemikiran, faktor sosio kultural, bahkan nilai-nilai kebenaran dan keadilan agama yang berbeda-beda menyebabkan para hakim memiliki pandangan berbeda pula dalam memutus. ${ }^{20}$ Perbedaan-perbedaan pendekatan yang dilakukan hakim dalam memutus suatu perkara ini, menurut M Syamsudin diidentifikasikan berdasarkan paradigma berpikir dan orientasi nilai-nilai yang dianut.

Dari sisi paradigma yang dianut hakim dibagi menjadi dua, yaitu paradigma positivistik dan paradigma diluar positivistik. ${ }^{21}$ Pertama, Paradigma Positivistik. Paradigma ini merupakan paradigma yang muncul sejak sosiologi diberi nama oleh Auguste Comte. Teori-teori positivistis bertumpu pada faham positivisme hukum yang dasar-dasar filsafatnya adalah aliran positif (positivism) yang berkembang di Perancis pada abad ke-19.22 Positivisme adalah suatu paham yang berpendapat bahwa setiap metodologi untuk menemukan kebenaran harus memperlakukan

20 M. Natsir Asnawi, Hermeneutika Putusan Hakim (Yogyakarta: UII Press, 2013). 181.

21 Asnawi. 182. Lukman Santoso dan Muhamad Fauzi Arifin, "Terobosan Hukum Hakim Terkait Pencabutan Surat Penolakan Perkawinan dalam Masa Iddah," Jurnal Yudisial 12, no. 3 (2020): 381-398.

22 A. Mukthie Fadjar, Teori-teori Hukum Kontemporer (Malang: Setara Press, 2014). 8. 
realitas sebagai sesuatu yang eksis. ${ }^{23}$ Pandangan ini sekaligus mengagungkan hukum tertulis atau hukum positif. Dengan adanya undang-undang kepastian hukum mungkin saja dapat diwujudkan, namun kelemahan dari undang-undang itu adalah sifatnya yang statis dan kaku. ${ }^{24}$ Kaum Positivisme Hukum kemudian membangun dan mengembangkan ilmu hukum yang diharapkan mampu berdiri sejajar dengan Ilmu-ilmu Alam yang bisa lebih menjamin kepastian dan bisa diprediksikan. Menurut pandangan kaum Positivis,demi kepastian hukum hakim harus selalu dibatasi oleh hukum positif. Tidak ada hukum yang melampaui peraturan yang berlaku. Bagaimanapun beratnya kasus (hard cases), peraturanperaturan hukum menjadi rujukan dan hakim diwajibkan untuk mengikutinya. ${ }^{25}$

Bagi penganut paradigma positivistik, Ius (keadilan) yang abstrak agar bisa diverifikasi harus dipositifkan (ius constitutum) terlebih dahulu menjadi rumusan hukum positif. Implikasinya, kepatuhan terhadap hukum positif dianggap adil, sebaliknya pelanggarannya dianggap tidak adil. Dengan kata lain, hukum positif menentukan keadilan. ${ }^{26}$

Kedua, Paradigma non- Positivistik. Popper dan Kuhn memandang bahwa paradigma selalu dalam perselisihan

23 Fadjar. 9. Lihat pula Achmad Ali, Menguak Teori Hukum dan Teori Peradilan (Jakarta: Kencana, 2012).

24 Ahmad Rifai, Penemuan Hukum oleh Hakim dalam Perspektif Hukum Progresif (Jakarta: Sinar Grafika, 2015). 28.

25 Putro, "Tinjauan Kritis-Filosofis Terhadap Paradigma Positivisme Hukum." 282.

26 Putro.272. Lihat pula Widodo Dwi Putro, "Perselisihan Sociological Jurisprudence dengan Mazhab Sejarah dalam Kasus "Merarik"," Jurnal Yudisial 6, no. 1 (March 11, 2013): 48-63. 
epistemologis, maka yang termasuk paradigma non-positivistik diantaranya: Hukum Kodrat, Mazhab Sejarah, Legal Realism, Marxist Theory of Law, Hukum Progresif, Critical Legal Studies, dan Feminism Legal Theory. ${ }^{27}$

Pendirian hakim terbagi pada dua, yaitu pendirian hakim yang memposisikan dirinya sebagai corong undang-undang dan pendirian hakim yang memposisikan dirinya sebagai kreator bagi terciptanya keadilan substantif. ${ }^{28}$ Hal ini sesuai dengan karakterisistik hakim non positivistik yang menjadikan undangundang bukan sebagai acuan dan sumber satu-satunya kebenaran dalam menangani perkara; diskresi hakim untuk melakukan penemuan mendapatkan tepat yang memadai. Sehingga hakim bukan menjadi corong undang-undang tetapi pembuat hukum yang menitikberatkan pada keadilan substantif dan menerapkan logika induktif dalam mendapatkan kebenaran hukum. ${ }^{29}$

Hakim melakukan pendekatan jika dilihat dari sisi nilainilai dan keyakinan, ada hakim yang memegang teguh idealisme hukum dengan berupaya memutus setiap perkara yang ditanganinya dengan seadil-adilnya. Sementara itu, ada hakim yang memutus dengan melihat sisi manfaat dari putusan yang akan diambilnya. Namun tidak sedikit hakim yang memutus

27 Putro, "Tinjauan Kritis-Filosofis Terhadap Paradigma Positivisme Hukum." 112.

28 Asnawi, Hermeneutika Putusan Hakim. 182.

29 Asnawi. 183. Lihat pula Rifai, Penemuan Hukum oleh Hakim dalam Perspektif Hukum Progresif. 
dengan menggabungkan nilai-nilai tersebut sehingga menjadi putusan yang lebih komprehensif. ${ }^{30}$

Tipologi hakim dalam proses memutus suatu perkara, dapat dibagi kepada dua tipologi, yaitu sebagai berikut: ${ }^{31}$ Pertama, Hakim yang pada memeriksa, mengadili, dan memutus perkara selalu bertanya kepada putusan hati nuraninya terlebih dahulu, kemudian mencari ketentuan hukum dalam pasal-pasal peraturan perundang-undangan untuk dijadikan dasar legitimasi. Hakim tipe ini telah berpikir secara sempurna karena menggunakan hati nuraninya atau kecerdasan spiritual sebagai dasar utama dalam mengadili. Logika yang dibangun dalam mengadili tidak hanya menggunakan "logika peraturan perundang-undangan" tetapi telah menggunakan "logika kepatutan sosial" (social reasonableness) dan "logika keadilan". Tipe hakim seperti ini yang merupakan sosok hakim yang progresif. Kedua, Hakim yang pada saat memeriksa, mengadili dan memutus perkara selalu bertanya kepada "perutnya" terlebih dahulu dan kemudian baru mencarikan pasal-pasal untuk memberi legitimasi.

Hakim yang berkualitas adalah hakim yang dalam proses mengadili selalu mendasarkan diri pada ketentuan hukum sebagai perwujudan asas keadilan, dan putusan tersebut terbukti mampu memberikan manfaat kepada para pihak yang berkepentingan dan masyarakat. ${ }^{32}$

30 Asnawi, Hermeneutika Putusan Hakim. 182.

31 Sutatiek. 45. Lihat pula Supandriyo, Asas Kebebasan Hakim dalam Penjatuhan Pidana.

32 Sutatiek, Menyoal Akuntabilitas Moral Hakim Pidana dalam Memeriksa, Mengadili, dan Memutus Perkara. 47. 
Inti keadilan yang ingin dicapai, diwujudkan, dan dipertanggungjawabkan dalam putusan hakim adalah agar putusan berorientasi pada keadilan hukum (legal justice), keadilan moral (moral justice), dan keadilan sosial (social justice). Keadilan hukum (legal justice), adalah keadilan berdasarkan hukum dan perundang-undangan. Sementara keadilan moral (moral justice) dan keadilan sosial (social justice) diterapkan hakim, dengan pernyataan bahwa: "hakim harus menggali nilai-nilai hukum yang hidup dalam masyarakat" (vide Pasal 5 ayat (1) Undang-Undang Nomor 48 Tahun 2009), yang jika dimaknai secara mendalam hal ini sudah masuk kedalam perbincangan tentang moral justice dan social justice. ${ }^{33}$

Sejatinya pelaksanaan tugas dan wewenag seorang hakim dilakukan dalam kerangka menegakkan kebenaran dan keadilan, dengan berpegang pada hukum, undang-undang dan nilai-nilai keadilan dalam masyarakat. Bagi kaum positivisik, keputusankeputusan hukum dapat didedukasikan secara logis dari peraturan-peraturan yang sudah ada lebih dahulu tanpa perlu menunjuk kepada tujuan-tujuan sosial, kebajikan, serta moralitas. Betapapun tidak adil dan terbatasnya bunyi undang-undang yang ada. Hukum adalah perintah undang-undang dan dari situ kepastian hukum bisa ditegakkan. ${ }^{34}$ Menurut Arbijoto, hakim dalam kapasitasnya sebagai makhluk individu mempunyai

33 Rifai, 83.

${ }^{34}$ Rifai, 83-84. Lihat pula Mila Karmila Adi, "Hakim Sebagai Pembentuk Hukum dalam Pandangan Pragmatis Realisme Bagi Kebebasan Hakim Indonesia dalam Pengambilan Putusan," Jurnal Hukum IUS QUIA IUSTUM 6, no. 12 (1999): 121-133. 
kebebasan sebagai bentuk kesempurnaan eksistensinya sebagai manusia. Kebebasan tersebut bukan berarti lepas dari segala kewajiban atau kekhawatiran dan tangung jawab, melainkan kebebasan sebagai makna eksistensi dan kemandirianya selaku manusia.Adanya paksaan, ikatan, beban adalah merupakan alienasi yang menekan manusia sedemikian rupa sehingga menghalang-alangi pelaksanaan dirinya sebagai manusia yang utuh dan mandiri. ${ }^{35}$

Sedangkan menurut Rifyal Ka'bah, makna dari sifat merdeka dalam kebebasan hakim menunjukkan kemandirian hakim dalam memutuskan perkara yang dihadapkan padanya tanpa campur tangan pihak lain, baik eksekutif maupun legislatif atau lainnya, namun kemerdekaan hakim tidaklah bersifat mutlak, tetapi dibatasi oleh hukum yang berlaku, disamping dipengaruhi oleh integritas dirinya dalam menetapkan apa yang adil dan tidak adil, hakim harus memutus sesuai dengan apa yang dipandang adil oleh hukum. ${ }^{36}$

Kaidah hukum yang mengandung nilai-nilai keadilan akan memudahkan bagi hakim dalam menjalankan putusannya, karena dengan integrasi moral yang tinggi dapat menerapkan kaidah hukum tersebut. Namun jika kaidah hukumnya samar bagi hakim, maka terbuka peluang menjatuhkan putusan berdasarkan

35 Asnawi, Hermeneutika Putusan Hakim. Lihat pula Supandriyo, Asas Kebebasan Hakim dalam Penjatuhan Pidana.

36 Edi Rosadi, "Putusan Hakim Yang Berkeadilan," Badamai Law Journal 1, no. 2 (2016): 381-400. 
keadilan dengan menggali nilai-nilai hukum yang hidup dalam masyarakat. ${ }^{37}$

Dalam perkembangannya lahirlah pemikiran hokum modern yang dikemukakan oleh Gustav Radbruch yang berusaha mengkombinasikan ketiga pandangan klasik (filsufis, normatif dan empiris) menjadi satu pendekatandengan masing-masing pendekatan dijadikan sebagai unsur pokok dan menjadi dasar pendekatan hukum "ala" Gustav Radbruch yang kemudian dikenal sebagai tiga nilai dasar hukum yang meliputi; keadilan (filosofis), kepastian hukum (juridis) dan kemanfaatan bagi masyarakat (sosiologis).

Gustav Radbruch memulai dengan pandangan bahwa masyarakat dan ketertiban memiliki hubungan yang sangat erat, bahkan dikatakan sebagai dua sisi mata uang, hal ini menunjukkan bahwa setiap komunitas (masyarakat) di dalamnya membutuhkan adanya ketertiban. Untuk mewujudkan ketertiban ini maka dalam masyarakat selalu terdapat beberapa norma seperti kebiasaan, kesusilaan dan hukum. ${ }^{38}$

Perbedaan antara ketiga norma di dalam masyarakat tersebut dimana kebiasaan lebih berorientasi pada perbuatanperbuatan yang memang lazim dilakukan sehari-hari menjadi norma, dan menurut Radbruch tatanan kebiasaan ini tidak sesuai dengan hukum atau kesusilaan. Kebiasaan lebih menggambarkan

37 Josef M. Monteiro, "Putusan Hakim dalam Penegakan Hukum di Indonesia," Jurnal Hukum Pro Justitia 25, no. 2 (2007).

38 Muhammad Muslih, "Negara Hukum Indonesia dalam Perspektif Teori Hukum Gustav Radbruch (Tiga Nilai Dasar Hukum)," Legalitas: Jurnal Hukum 4, no. 1 (2017): 130-152. 
posisi kebalikan dari kesusilaan, kalau kebiasaan mutlak berpegangan pada kenyataan tingkah laku orang, maka kesusilaan justru berpegang pada ideal yang masih harus diwujudkan dalam masyarakat. Untuk itu tolok ukur penilaian terhadap tindakan yang diterima atau ditolak didasarkan pada idealisme manusia yakni insan kamil atau manusia sempurna. Norma hukum lebih berorientasi pada dunia ideal (kesusilaan) dan kenyataan (kebiasaan), dengan demikian maka untuk memenuhi unsur ideal, hukum harus mengakomodir nilai filosofis dan guna memenuhi tuntutan kenyataan hukum harus memasukkan unsur sosiologis. ${ }^{39}$

Realisasi konsep Gustav Radbruch tentang tiga nilai dasar hukum yang meliputi, aspek keadilan, kemanfaatan dan kepastian hukum ini sudah barang tentu berpotensi menimbulkan ketegangan di antara masing-masing aspek. Ada kalanya keadilan bertentangan dengan manfaat, atau lainkali keadilan bertentangan dengan kepastian hukum juga dimungkinkan adanya ketegangan antara manfaat dengan keadilan. Guna mengantisipasi kondisi tersebut Gustav Radbruch memberikan jalan keluar melalui ajaran prioritas baku, dengan memberikan patokan dalam memutus suatu perkara, dimana prioritas pertama keadilan, kedua manfaat dan ketiga kepastian hukum. Ajaran prioritas baku relatif lebih bijak dan arif, dibandingkan dengan ajaran ekstrim seperti Aliran Hukum Etis yang hanya berfokus pada keadilan, aliran Utilitarian yang hanya berfokus pada kegunaan hukum dan Aliran Dogmatik

39 Fencem Wantu, "Mewujudkan Kepastian Hukum, Keadilan dan Kemanfaatan dalam Putusan Hakim di Peradilan Perdata," Jurnal Dinamika Hukum 12, no. 3 (2012): 479-489. 
Legalistik (positivisme hukum) yang hanya berfokus pada kepastian hukum. ${ }^{40}$ Dalam praktik peradilan, sangat sulit bagi seorang hakim mengakomodir ketiga asas tersebut di dalam satu putusan. Dalam menghadapi keadaan ini, hakim harus memilih salah satu dari ketiga asas tersebut untuk memutuskan suatu perkara dan tidak mungkin tiga asa tersebut dapat tercakup sekaligus dalam satu putusan (asas prioritas yang kasuistis). Jika diibaratkan dalam sebuah garis, hakim dalam memeriksa dan memutuskan suatu perkara (bergerak) diantara 2 titik pembatas dalam garis tersebut, yaitu apakah berdiri pada titik keadilan atau kepastian hukum, sedangkan titik kemanfaatan sendiri berada di antara keduanya. ${ }^{41}$

Sebagaimana menurut Sudikno Mertokusumo, ketiga asas tersebut harus dilaksanakan secara kompromi yaitu dengan cara menerapkan ketiga-tiganya secara berimbang atau proporsional, sehingga tidak perlu mengikuti asas prioritas sebagaimana yang dikemukakan oleh Gustav Radbruch, tetapi seharusnya mengikuti asas prioritas yang kasuistis atau sesuai dengan kasus yang dihadapi. 42

\section{ANALISIS PENAFSIRAN HUKUM HAKIM ATAS PENOLAKAN ISBAT NIKAH PERSPEKTIF STUDI HUKUM KRITIS}

40 Muslih, "Negara Hukum Indonesia dalam Perspektif Teori Hukum Gustav Radbruch (Tiga Nilai Dasar Hukum)."

41 Rifai, Penemuan Hukum oleh Hakim dalam Perspektif Hukum Progresif. 133.

42 Marwan Mas, "Penguatan Argumentasi Fakta-Fakta Persidangan Dan Teori Hukum Dalam Putusan Hakim," Jurnal Yudisial 5, no. 3 (2012): 283-297. Lihat pula Rosadi, "Putusan Hakim Yang Berkeadilan." 


\section{Penafsiran Hukum Hakim dalam Perkara Penolakan Isbat Nikah}

Dalam penetapan Pengadilan Agama Ponorogo Nomor: 402/Pdt. P/2018/PA. Po, menerangkan bahwa saat Pemohon mengajukan permohonan isbat nikah Pemohon I dan Pemohon Pemohon II mengajukan permohonan isbat nikah agar majelis hakim menetapkan pernikahan antara Pemohon I dan Pemohon II yang telah dilangsungkan secara agama Islam di Desa Mlancar Kecamatan Sukorejo dengan wali muhakkam pada 21 November 2017 adalah sah, karena dengan pengesahan nikah tersebut hendak digunakan untuk mengurus dokumen kependudukan para pemohon. ${ }^{43}$

Namun majelis hakim dalam putusannya memutuskan bahwa pernikahan Pemohon I dan Pemohon II dengan wali muhakkam telah tidak sesuai dengan hukum dan peraturan perundangan yang berlaku. Oleh karenanya majelis hakim dalam musyawarahnya berpendapat bahwa permohonan para Pemohon tidak berdasarkan hukum, sehingga hakim dalam penetapan isbat nikah ini menjatuhkan amar putusan bahwa permohonan para Pemohon patut untuk ditolak. ${ }^{44}$

Masyarakat membutuhkan ketertiban serta keteraturan dan oleh karena itu membutuhkan hukum. Tetapi masyarakat pasti menolak untuk diatur oleh hukum yang cacat. Maka cara-cara

43 Siti Ummu Adillah, "Analisis Hukum Terhadap Faktor-faktor yang Melatarbelakangi Terjadinya Nikah Sirri dan Dampaknya Terhadap Perempuan (Istri) dan Anak-Anak," Jurnal Dinamika Hukum 11 (2011): 104-112. Lihat pula Tahimi, Kajian Fiqih Nikah Lengkap., 12.

44 Dokumen Putusan Pengadilan 
untuk lebih "mengadilkan," "membenarkan" "meluruskan" serta "membumikan" hukum menjadi pekerjaan yang tak dapat ditawartawar lagi. Cara-cara tersebut dilayani oleh penafsiran teks-teks hukum. ${ }^{45}$

Setelah mencermati penetapan hakim Pengadilan Agama Ponorogo tentang isbat nikah diatas, penetapan diatas tergolong perkara yang tidak kompleks dan jelas (clear cases) karena dapat secara langsung ditemukan jawabannya dalam hukum positif yang tersedia. Akan tetapi setiap kasus (baik "hard cases" maupun "clear cases") pada hakikatnya unik, sehingga memerlukan interpretasi hukum yang baru, atau dengan kata lain tidak pernah ada dua perkara yang sepenuhnya serupa. Karena itu, hakim harus melakukan "fresh judgement" untuk menemukan hukum yang tepat.Ilmu hukum sama sekali tidak dapat menganggap masalah penafsiran sebagai hal kecil dan dipinggirkan. Hukum tidak akan berjalan tanpa penafsiran, oleh karena hukum membutuhkan pemaknaan lebih lanjut agar menjadi lebih adil dan membumi. Membuat hukum (legislation) adalah satu hal dan menafsirkan hukum yang sudah dibuat merupakan keharusan berikutnya. 46

Peneliti dalam menganalisis Penetapan Pengadilan Agama Ponorogo Nomor: 402/Pdt.P/2018/PA.Po. menggunakan teori interpretasi hukum yang merupakan salah satu dari metode

45 Satjipto, Hukum Progresif, 123. Lihat pula Rifai, Penemuan Hukum Oleh Hakim dalam Perspektif Hukum Progresif.

46 Putro, "Tinjauan Kritis-Filosofis Terhadap Paradigma Positivisme Hukum." 272. 
penemuan hukum. ${ }^{47}$ Berikut ini beberapa analisis yang dilakukan oleh peneliti mengenai metode interpretasi hukum yang digunakan majelis hakim dalam penetapan Pengadilan Agama Ponorogo Nomor: 402/Pdt.P/2018/PA.Po. tentang penolakan isbat nikah karena menikah sirri menggunakan wali muhakkam, diantaranya: Pertama, Interpretasi Sistematis (logis). Interpretasi sistematis yaitu menafsirkan peraturan perundang-undangan dengan menghubungkannya dengan undang-undang lain. Maka tidak satupun dari peraturan dari peraturan perundangan tersebut dapat ditafsirkan seakan-akan berdiri sendiri, tetapi harus selalu dipahami dalam kaitannya dengan jenis peraturan yang lainnya. Berdasarkan analisis peneliti terhadap penetapan ini, majelis hakim dalam penemuan hukumnya telah sesuai dengan metode interpretasi sistematis, tekait penetapan sah atau tidak sahnya pernikahan para pemohon yang menggunakan wali muhakkam. Hal ini terlihat dalam pertimbangan hukumnya, bahwa majelis hakim secara sistematis mengaitkan beberapa peraturan perundang-undangan dengan menggunakan sumber hukum positif dan juga sumber hukum Islam, diantaranya berdasarkan hadis Rasulullah SAW tentang wali nikah yang diriwayatkan oleh Ibnu Hibban yang artinya:"Tidak ada pernikahan, kecuali dengan wali dan kedua saksi yang adil. Jika ada pernikahan tanpa itu maka pernikahan dianggap batal" (HR. Ibnu Hibban).

47 Jaenal Aripin, Peradilan Agama dalam Bingkai Reformasi Hukum di Indoensia (Jakarta: Kencana, 2008). 468. 
Dan Pasal 2 Ayat (1) Undang-Undang Nomor 1 Tahun 1974 Tentang Perkawinan menegaskan bahwa perkawinan adalah sah, apabila dilakukan menurut hukum masing-masing agamanya dan kepercayaannya itu. Ketentuan tersebut selaras dengan Pasal 4 Kompilasi Hukum Islam (Instruksi Presiden Nomor 1 Tahun 1991 juncto Keputusan Menteri Agama RI Nomor 154 Tahun 1991) yang menyebutkan bahwa perkawinan adalah sah, apabila dilakukan menurut hukum Islam sesuai dengan ketentuan Pasal 2 Ayat (1) Undang-Undang Nomor 1 Tahun 1974 Tentang Perkawinan.

Serta sesuai Pasal 20 Kompilasi Hukum Islam wali nikah diklasifikasikan menjadi dua yakni wali nasab dan wali hakim sedangkan Pasal 23 Kompilasi Hukum Islam menyebutkan bahwa wali hakim baru dapat bertindak sebagai wali nikah apabila wali nasab tidak ada atau tidak mungkin menghadirkannya atau tidak diketahui keberadaannya/gaib atau enggan /adlal. Kemudian Pasal 1 ayat (2) Peraturan Menteri Agama Nomor 30 Tahun 2005 Tentang Wali Hakim disebutkan bahwa yang dimaksud dengan wali hakim adalah "Kepala Kantor Urusan Agama yang ditunjuk oleh Menteri Agama untuk bertindak sebagai wali nikah bagi calon mempelai wanita yang tidak mempunyai wali." Sedangkan terungkap dalam fakta, bahwa pernikahan Pemohon I dengan Pemohon II yang bertindak sebagai wali nikah adalah wali muhakkam dari tokoh/ahli agama setempat.

Berdasarkan interpretasi sistematis terhadap pasal dan hadis tersebut diatas, bahwa perkawinan yang sah menurut agama berarti sah menurut peraturan perundang-undangan. Maka 
sahnya pernikahan menurut agama Islam ditentukan antara lain mutlak harus ada wali nikah sebagaimana disebutkan dalam hadis diatas. Adapun wali hakim yang berhak menjadi wali nikah adalah Kepala Kantor Urusan Agamayang ditunjuk oleh Menteri Agama dan bukan dari tokoh/ahli agama setempat.

Kedua, Metode Interpretasi Gramatikal. Majelis hakim dalam putusan ini juga telah sesuai dengan metode interpretasi gramatikal. Biasanya interpretasi gramatikal dilakukan oleh hakim bersamaan dengan interpretasi logis, yaitu memakai berbagai aturan hukum yang ada melalui penalaran hukum untuk diterapkan terhadap teks yang kabur atau kurang jelas. ${ }^{48}$

Hal ini terlihat ketika majelis hakim mempertimbangkan sebelum memberikan penetapan isbat nikah, terlebih dulu majelis hakim memeriksa apakah perkawinan tersebut telah memenuhi rukun dan syarat perkawinan serta ada atau tidaknya larangan pernikahan menurut peraturan perundang-undangan yang berlaku dengan menggunakan dengan metode interpretasi gramatikal terhadap Pasal 2 ayat 1 Undang-undang Perkawinan No. 1 Tahun 1974 yang berbunyi: “ Perkawinan adalah sah, apabila dilakukan menurut hukum masing-masing agamanya dan kepercayaannya itu. Ketentuan tersebut selaras dengan Pasal 4 KHI (Instruksi Presiden Nomor 1 Tahun 1991 juncto Keputusan Menteri Agama RI Nomor 154 Tahun 1991) yang menyebutkan bahwa perkawinan adalah sah, apabila dilakukan menurut hukum Islam sesuai dengan ketentuan Pasal 2 Ayat (1) UU No 1 Tahun 
1974 Tentang Perkawinan. Kemudian terbukti bahwa pernikahan para pemohon tidak sah dan tidak sesuai dengan tata cara perkawinan agama Islam.

Sesuai dengan hasil interpretasi hukum oleh majelis hakim diatas pernikahan para pemohon terbukti tidak sah secara agama Islam. Karena sahnya nikah menurut agama Islam ditentukan dengan adanya wali nikah sebagaimana hadis Rasulullah SAW yang diriwayatkan oleh Ibnu Hibban. Dalam Pasal 20 Kompilasi Hukum Islam membagi wali nikah menjadi dua yaitu wali nasab dan wali hakim dan Pasal 1 (ayat) 2 Peraturan Menteri Agama Nomor 30 Tahun 2005 menyebutkan bahwa wali hakim adalah Kepala Kantor Urusan Agama yang ditunjuk oleh Menteri Agama. Hal inilah yang menjadi salah satu dari pertimbangan hakim untuk menolak permohonan isbat nikah dalam perkara Nomor: 402/Pdt. P/2018/PA.Po.

\section{Penolakan Isbat Nikah Perspektif Studi Hukum Kritis}

Dalam perspektif sistem peradilan, Hakim mempunyai peran yang sangat penting. Selain sebagai penegak hukum dan penegak keadilan, hakim juga sebagai pejabat negara yang mengemban tugas mulia dalam mewujudkan negara hukum dan selalu berupaya memberikan kepastian hukum dan kemanfaatan di tengah-tengah masyarakat melalui putusan hukumnya di pengadilan. Oleh karenanya kepastian hukum, keadilan, dan 
kemanfaatan harus menjadi konsen hakim dalam memutuskan perkara. $^{49}$

Hakim dalam memutuskan suatu perkara, secara kasuistis, selalu dihadapkan pada ketiga asas, yaitu asas kepastian hukum, asas keadilan dan asas kemanfaatan. Sebagaimana menurut Sudikno Mertokusumo, ketiga asas tersebut harus dilaksanakan secara kompromi yaitu dengan cara menerapkan ketiga-tiganya secara berimbang atau proporsional, sehingga tidak perlu mengikuti asas prioritas sebagaimana yang dikemukakan oleh Radbruch, tetapi seharusnya mengikuti asas prioritas yang kasuistis atau sesuai dengan kasus yang dihadapi. ${ }^{50}$

Dalam praktik peradilan, sangat sulit bagi seorang hakim mengakomodir ketiga asas tersebut di dalam satu putusan. Dalam menghadapi keadaan ini, hakim harus memilih salah satu dari ketiga asas tersebut untuk memutuskan suatu perkara dan tidak mungkin tiga asas tersebut dapat tercakup sekaligus dalam satu putusan (asas prioritas yang kasuistis). Jika diibaratkan dalam sebuah garis, hakim dalam memeriksa dan memutuskan suatu perkara (bergerak) diantara 2 titik pembatas dalam garis tersebut, yaitu apakah berdiri pada titik keadilan atau kepastian hukum, sedangkan titik kemanfaatan sendiri berada di antara keduanya. ${ }^{51}$

${ }^{49}$ Aripin, Peradilan Agama dalam Bingkai Reformasi Hukum di Indoensia. 464. 132.

50 Rifai, Penemuan Hukum oleh Hakim dalam Perspektif Hukum Progresif.

51 Rifai. 133. Lihat pula Andi Suherman, "Implementasi Independensi Hakim dalam Pelaksanaan Kekuasaan Kehakiman," SIGn Jurnal Hukum 1, no. 1 (2019): 42-51. 
Mengingat dalam perkara tersebut bahwa pada saat pernikahan, wali nikah yang mengijabkan adalah wali yang ditunjuk pemohon 2 yaitu seorang kyai yang merupakan tetangga Pemohon 1 karena pada saat itu pemohon 2 tidak memiliki wali nasab yang mana ayah dari pemohon 2 telah meninggal dunia, demikian juga dengan kakek pemohon dan tidak ada lagi wali nasab yang berhak untuk menjadi wali nikah. Oleh karena itu menurut pertimbangan hakim Pengadilan Agama Ponorogo bahwa wali Muhhakkam yang di tuntuk oleh pemohon 2 telah tidak sesuai dengan pasal 23 Kompilasi Hukum Islam "(1) Wali hakim baru dapat bertindak sebagai wali nikah apabila wali nasab tidak ada atau tidak mungkin menghadirkannya atau tidak diketahui tempat tinggalnya atau gaib atau adlal atau enggan". Karena wali hakim yang dimaksud dalam Pasal 1 ayat (2) Peraturan Menteri Agama Nomor 30 Tahun 2005 Tentang Wali Hakim disebutkan bahwa yang dimaksud dengan wali hakim adalah "Kepala Kantor Urusan Agama yang ditunjuk oleh Menteri Agama untuk bertindak sebagai wali nikah bagi calon mempelai wanita yang tidak mempunyai wali." 52

Dalam penetapan penolakan isbat nikah ini peneliti melihat bahwa paradigma yang dianut oleh hakim dalam memutus perkara adalah paradigma positivistik. Dimana kaum positivistik mengganggap hukum positif dapat memberikan kepastian hukum karena kita mengenali apa yang dilarang dan diperbolehkan dari

52 Dokumen Penetapan Pengadilan Agama Ponorogo Perkara Nomor: 402/Pdt.P/2018/PA.PO., 9. 
hukum positif tersebut. Karena itu, ius (keadilan) yang abstrak agar bisa diverifikasi harus dipositifkan (ius constitutum) terlebih dulu menjadi rumusan hukum positif. Implikasinya, kepatuhan terhadap hukum positif dianggap adil, sebaliknya pelanggarannya dianggap tidak adil. Dengan kata lain, hukum positif menentukan keadilan. ${ }^{53}$

Menurut pertimbangan hakim bahwa di Indonesia sekarang di setiap kecamatan terdapat Kantor Urusan Agama dan di setiap Kantor Urusan Agama terdapat wali hakim dari kalangan pegawai Kantor Urusan Agama yang ditunjuk oleh pemerintah, maka tidak ada alasan mempelai wanita menunjuk Wali Muhakam dari tokoh /ahli agama setempat sebagai wali nikahnya.

Pada saat hakim menetapkan perkara isbat nikah ini lebih dekat mengarah kepada asas kepastian hukum, maka secara otomatis hakim akan menjauh dari titik keadilan. Sebaliknya, kalau hakim menjatuhkan putusan lebih dekat mengarah kepada keadilan, maka secara otomatis pula hakim akan menjauhi titik kepastian hukum. Disinilah letak batas-batas kebebasan hakim, di mana hakim hanya dapat bergerak diantara 2 titik pembatas tersebut. Dengan suatu pertimbangan yang bernalar, seorang hakim akan menentukan kapan dirinya berada di dekat titik kepastian hukum, dan kapan harus berada di dekat titik keadilan. Jadi, tidaklah benar sepenuhnya bahwa hakim dalam memeriksa dan menjatuhkan putusan suatu perkara bersifat bebas dan tanpa

53 Putro, “Tinjauan Kritis-Filosofis Terhadap Paradigma Positivisme Hukum." 272. Lihat pula Habibul Umam Taqiuddin, "Penalaran Hukum (Legal Reasoning) dalam Putusan Hakim," JISIP (Jurnal Ilmu Sosial dan Pendidikan) 1, no. 2 (2019). 
batas. ${ }^{54}$ Mencermati penetapan hakim dari kacamata konsep Gustav Radbruch tentang tiga nilai dasar hukum yang meliputi, aspek keadilan (filosofis), kepastian hukum (juridis) dan kemanfaatan bagi masyarakat (sosiologis) ini sudah tentu berpotensi menimbulkan ketegangan di antara masing-masing aspek. Ada kalanya keadilan bertentangan dengan manfaat, atau lain kali keadilan bertentangan dengan kepastian hukum juga dimungkinkan adanya ketegangan antara manfaat dengan keadilan. Guna mengantisipasi kondisi tersebut Gustav Radbruch memberikan jalan keluar melalui ajaran prioritas baku, dengan memberikan patokan dalam memutus suatu perkara, dimana prioritas pertama keadilan, kedua manfaat dan ketiga kepastian hukum..$^{55}$

Namun dalam perkara ini hakim memutuskan untuk tidak mengabulkan permohonan isbat nikah demi mendahulukan nilai kepastian hukum dari pada nilai keadilan dan nilai kemanfaatan. Maka demi kepastian hukum, maka penetapan ini dapat memberi kejelasan hukum atas sah tidaknya perkawinan tersebut meskipun dalam hal ini dinilai tidak adil.

Selain itu ada perbedaan antara wali muhakkam dan wali hakim, wali muhakkam adalah orang yang diangkat kedua calon suami istri untuk bertindak sebagai wali dalam akad nikah mereka. Sedangkan wali hakim adalah wali yang ditunjuk oleh Menteri

54 Wantu, "Mewujudkan Kepastian Hukum, Keadilan dan Kemanfaatan dalam Putusan Hakim di Peradilan Perdata." Lihat pula Supandriyo, Asas Kebebasan Hakim dalam Penjatuhan Pidana.

55 Muslih, "Negara Hukum Indonesia dalam Perspektif Teori Hukum Gustav Radbruch (Tiga Nilai Dasar Hukum).” 144. 
Agama yang diberi kewenangan untuk bertindak sebagai wali nikah. Disisi lain sudah terjadi hubungan suami-istri dan sudah menghasilkan anak dan juga tidak ada halangan pernikahan baik menurut Undang-Undang maupun hukum islam, hanya saja salah satu rukun nikah tidak terpenuhi yaitu menggunakan wali muhakkam yang dianggap ahli agama, sehingga pernikahan batal.

Padahal dalam pelaksanaannya pernikahan para pemohon telah memenuhi syarat dan rukun berupa wali, dua saksi, ijab kabul dan tidak menyalahi larangan perkawinan termasuk publikasi perkawinan kepada khalayak ramai. Jadi umumnya pelaksanaan "kawin Kyai" selaras dengan ketentuan agama yang termuat dalam fikih yang populer di Indonesia tanpa mengikuti prosedur hukum yang resmi untuk mendapatkan legitimasi dan perlindungan yuridis. ${ }^{56}$

Penetapan isbat nikah diatas berdasarkan pendapat Radbruch, tatanan kebiasaan ini tidak sesuai dengan hukum atau kesusilaan. Kebiasaan lebih menggambarkan posisi kebalikan dari kesusilaan, kalau kebiasaan mutlak berpegangan pada kenyataan tingkah laku orang, maka kesusilaan justru berpegang pada ideal yang masih harus diwujudkan dalam masyarakat. Norma hukum lebih berorientasi pada dunia ideal (kesusilaan) dan kenyataan (kebiasaan), dengan demikian maka untuk memenuhi unsur kepastian hukum (ideal), hukum harus mengakomodir nilai

56 Al Farabi, "Budaya 'Kawin Kyai' Studi Terhadap Praktek Nikah Sirri di Desa Sinarrancang, Kecamatan Mundu, Kabupaten Cirebon," Al-Ahwal: Jurnal Hukum Keluarga Islam 4, no. 1 (September 26, 2016): 21-56. Lihat pula Maksum, "Telaah Kritis Terhadap Praktik Perkawinan di Bawah Tangan di Indonesia." 
keadilan (filosofis) dan guna memenuhi tuntutan kenyataan hukum harus memasukkan unsur kemanfaatan bagi masyarakat (sosiologis). ${ }^{57}$

Selanjutnya CLS menolak anggapan tentang netralitas obyektivitas hukum sebagaimana yang diyakini Positivisme Hukum. Sebab menurut Roberto M. Unger, setiap metode hukum tertentu akan menghasilkan pilihan hukum tertentu. Dengan kata lain metode hukum yang dipilih oleh praktisi hukum akan menghasilkan keputusan hukum yang tertentu pula. Setiap pembuatan hukum dengan sendirinya mencerminkan nilai-nilai sosial-politik tertentu. Tentang hal ini Unger mengkritik obyektivisme dan formalisme, "The first concern has been the critique of formalism and objectivism."CLS menusuk jantung formalisme hukum sebagaimana dianut sistem hukum liberal dengan mengajukan keberatan, yaitu terhadap konsep the rule of law, karena yang ada adalah the rule of the rulers. ${ }^{58}$

Positivisme Hukum yang dianut hakim menganganggap hukum sebagai sebuah sistem yang netral, obyektif dan otonom. Dengan kata lain, hukum merupakan norma yang terlepas dari politik, moral, kebudayaan atau kebiasaan sehari-hari. Perumusan dan praktek hukum tidak dilakukan secara terstruktur secara

57 Muslih, "Negara Hukum Indonesia dalam Perspektif Teori Hukum Gustav Radbruch (Tiga Nilai Dasar Hukum).” 143.

58 Putro, "Tinjauan Kritis-Filosofis Terhadap Paradigma Positivisme Hukum." 134. 
rasional dan logis (metode deduktif) berdasarkan konsep dan asas-asas hukum tertentu. 59

Positivisme menuntut bahwa memutuskan suatu perkara harus menunjuk pada ketetapan dan kepastian. Namun studi hukum kritis menganggap bahwa klaim atas suatu kepastian adalah palsu, baik aturan hukum maupun ajaran prinsip-prinsip hukum sehingga tidak bisa digunakan untuk menentukan hasil akhir suatu kasus. Berbagai aturan hukum dan berbagai kata dalam aturan sangat rentan terhadap berbagai penafsiran tergantung interpretasi yang digunakan hakim. ${ }^{60}$ Dalam penetapan isbat nikah diatas hakim tidak melakukan terobosan karena hukum positif dianggap telah mampu menjawab kasus penolakan isbat nikah karena menikah siri dengan menunjuk wali nikah seorang wali muhakkam, sehingga tidak celahnya dan telihat jelas. Pandangan semacam itu melukiskan hukum mampu menghasilkan jawaban yang pasti terhadap semua kasus sehingga dianggap kasus yang ringan. Namun sebenarnya setiap perkara yang diputus pastinya masalahnya bebeda-beda.

\section{KESIMPULAN}

Dari hasil penelitian dapat disimpulkan bahwa, Pertama, bahwasannya penetapan nomor: 402/Pdt.P/2018/PA.Po tersebut

59 Putro. 133. Lihat pula Muslih, "Negara Hukum Indonesia dalam Perspektif Teori Hukum Gustav Radbruch (Tiga Nilai Dasar Hukum)."

60 Muchammad Ali Safa'at, "Gerakan Studi Hukum Kritis," accessed June 29, 2019. Lihat pula Sippah Chotban, "Sudi Kritis Pernikahan Bawah Umur Perpektif UUP No 16 Tahun 2019 Dan Gender Analisis," Al-Risalah Jurnal Ilmu Syariah dan Hukum 19, no. 2 (2020): 208-226. 
termasuk perkara yang tidak kompleks dan jelas (clear cases). Sehingga interpretasi hukum yang digunakan majelis hakim dalam penetapan ini adalah Interpretasi sistematis. Sedangkan majelis hakim dalam perkara ini menggunakan metode interpretasi gramatikal. Hal ini dapat dilihat cukup jelas salah satunya dari dasar pertimbangan hukum hakim menolak permohonan isbat nikah adalah hadis Rasulullah tentang harus adanya wali nikah yang diriwayatkan oleh Ibnu Hibban, Pasal 20 dan Pasal 23 KHI, Pasal 1 ayat (2) PMA No 30 Tahun 2005, Pasal 2 ayat (1) UU No 1 Tahun 1974 Tentang Perkawinan.

Kedua, perspektif studi hukum kritis dalam kasus penolakan isbat nikah menganut paradigma positivistik dengan tidak melakukan terobosan hukum karena undang-undang dianggap telah mampu menjawab kasus nikah siri dengan menunjuk wali muhakkam. Hakim lebih mendahulukan nilai kepastian hukum daripada nilai keadilan dan nilai kemanfaatan, sehingga berseberangan dengan ajaran prioritas baku Gustav Radbruch. Dengan hasil temuan ini, rekomendasi yang diberikan atas penelitian ini, pertama, kepada hakim hendaknya pertimbangan hukum yang digunakan tidak hanya memperhatikan aspek yuridis tanpa mempertimbangkan aspek filosofis dan aspek sosiologis. Kedua, dalam kasus ini yang sangat penting harus diperhatikan adalah pemeliharaan terhadap kesejahteraan dan hak keperdataan anak dari hasil pernikahan tersebut. Ketiga, bagi pasangan yang ingin melakukan perkawinan hendaknya mencatatkan perkawinan untuk mewujudkan 
ketertiban perkawinan dalam masyarakat serta melindungi hakhak suami, istri dan anak.

\section{DAFTAR PUSTAKA}

Adi, Mila Karmila. "Hakim Sebagai Pembentuk Hukum dalam Pandangan Pragmatis Realisme Bagi Kebebasan Hakim Indonesia Dalam Pengambilan Putusan." Jurnal Hukum IUS QUIA IUSTUM 6, no. 12 (1999).

Adillah, Siti Ummu. "Analisis Hukum Terhadap Faktor-faktor yang Melatarbelakangi Terjadinya Nikah Sirri dan Dampaknya Terhadap Perempuan (Istri) Dan Anak-Anak." Jurnal Dinamika Hukum 11 (2011).

Ali, Achmad. Menguak Teori Hukum dan Teori Peradilan. Jakarta: Kencana, 2012.

Anshori, Abdul Ghofur. Hukum Perkawinan Islam. Yogyakarta: UII Press, 2011.

Aripin, Jaenal. Peradilan Agama dalam Bingkai Reformasi Hukum di Indoensia. Jakarta: Kencana, 2008.

Asnawi, M. Natsir. Hermeneutika Putusan Hakim. Yogyakarta: UII Press, 2013.

Bahrum, Mukhtaruddin. "Legalisasi Nikah Sirri Melalui Isbat Nikah Menurut Kompilasi Hukum Islam.” Jurnal Diskursus Islam 1, no. 2 (August 29, 2013).

Balitbang Kemenag. Menelusuri Makna di Balik FenomenaPerkawinan di Bawah Umur dan Perkawinan Tidak Tercatat. Jakarta: Puslitbang Kehidupan Keagamaan, 2013.

Chotban, Sippah. "Sudi Kritis Pernikahan Bawah Umur Perpektif UUP No 16 Tahun 2019 dan Gender Analisis." Al-Risalah Jurnal Ilmu Syariah dan Hukum 19, no. 2 (2020).

Diantha, Made Pasek. Metodologi Penelitian Hukum Normatif dalam Justifikasi Teori Hukum. Jakarta: Prenada Media Grup, 2017. 
Dokumen Penetapan Pengadilan Agama Ponorogo Perkara Nomor 402/Pdt.P/2018/PA.PO.

Fadjar, A. Mukthie. Teori-teori Hukum Kontemporer. Malang: Setara Press, 2014.

Farabi, Al. “Budaya 'Kawin Kyai' Studi Terhadap Praktek Nikah Sirri di Desa Sinarrancang, Kecamatan Mundu, Kabupaten Cirebon." Al-Ahwal: Jurnal Hukum Keluarga Islam 4, no. 1 (September 26, 2016).

Hadikusuma, Hilman. Hukum Perkawinan Indonesia Menurut: Perundangan, Hukum Hukum Agama. Bandung: CV. Mandar Maju, 2007.

Halimah, Nur. "Wali Nikah Menurut Imam Malik dan Imam Syafi'i." Skripsi, IAIN Ponorogo, 2017.

Kementerian Agama RI, Al-Qur'an dan Terjemahan. Jakarta: PT. Sinergi Pustaka Indonesia, 2012.

Maksum, Ghufron. "Telaah Kritis Terhadap Praktik Perkawinan di Bawah Tangan di Indonesia." Kordinat/ Jurnal Komunikasi Antar Perguruan Tinggi Agama Islam 16, no. 1 (2017).

Mas, Marwan. "Penguatan Argumentasi Fakta-fakta Persidangan dan Teori Hukum dalam Putusan Hakim." Jurnal Yudisial 5, no. 3 (2012).

Monteiro, Josef M. "Putusan Hakim dalam Penegakan Hukum di Indonesia." Jurnal Hukum Pro Justitia 25, no. 2 (2007).

Muslih, Muhammad. "Negara Hukum Indonesia dalam Perspektif Teori Hukum Gustav Radbruch (Tiga Nilai Dasar Hukum)." Legalitas: Jurnal Hukum 4, no. 1 (2017).

Mustika, Dian. "Pencatatan Perkawinan dalam Undang-undang Hukum Keluarga di Dunia Islam." Inovatif: Jurnal Ilmu Hukum 4 , no. 5 (2011).

Musyafa'ah, Nur Lailatul. "Studi Hukum Perkawinan Islam di Indonesia Perspektif Gender." Al-Hukama' 4, no. 2 (2014).

Putro, Widodo Dwi. "Perselisihan Sociological Jurisprudence dengan Mazhab Sejarah dalam Kasus "Merarik"." Jurnal Yudisial 6, no. 1 (March 11, 2013). 
_—_. "Tinjauan Kritis-Filosofis Terhadap Paradigma Positivisme Hukum." Disertasi, Universitas Indonesia, 2011.

PMA Nomor 30 Tahun 2005, tentang Wali Hakim.

Rifai, Ahmad. Penemuan Hukum oleh Hakim dalam Perspektif Hukum Progresif. Jakarta: Sinar Grafika, 2015.

Rosadi, Edi. "Putusan Hakim Yang Berkeadilan." Badamai Law Journal 1, no. 2 (2016).

Safa'at, Muchammad Ali. "Gerakan Studi Hukum Kritis." Accessed June 29, 2019.

Santoso, Lukman, and Muhamad Fauzi Arifin. "Terobosan Hukum Hakim Terkait Pencabutan Surat Penolakan Perkawinan dalam Masa Iddah." Jurnal Yudisial 12, no. 3 (2020).

Sihab, Alwi. "Peran Kiai Sebagai Wali Muhakkam." Skripsi, UIN Maliki, 2013.

Soekanto, Soerjono. Pengantar Penelitian Hukum. Jakarta: UI Press, 2010.

Subekti, Trusto. "Sahnya Perkawinan Menurut Undang-undang Nomor 1 Tahun 1974 Tentang Perkawinan Ditinjau dari Hukum Perjanjian." Jurnal Dinamika Hukum 10, no. 3 (2010).

Suherman, Andi. "Implementasi Independensi Hakim dalam Pelaksanaan Kekuasaan Kehakiman." SIGn Jurnal Hukum 1, no. 1 (2019).

Supandriyo. Asas Kebebasan Hakim dalam Penjatuhan Pidana. Yogyakarta: Arti Bumi Intaran, 2019.

Sutatiek, Sri. Menyoal Akuntabilitas Moral Hakim Pidana dalam Memeriksa, Mengadili, dan Memutus Perkara. Yogyakarta: Aswaja Pressindo, 2013.

Syukur, Abdul Kadir. "Pernikahan dengan Wali Muhakkam (Studi Tentang Implikasi dan Persepsi Ulama di Kota Banjarmasin)." Syariah: Jurnal Hukum dan Pemikiran 14, no. 1 (2014).

Taqiuddin, Habibul Umam. "Penalaran Hukum (Legal Reasoning) dalam Putusan Hakim." JISIP (Jurnal Ilmu Sosial dan Pendidikan) 1, no. 2 (2019).

Tim Penyusun, Kompilasi Hukum Islam.Bandung: Nuansa Aulia, 


\section{5.}

Undang-undang Nomor 1 Tahun 1974 Tentang Perkawinan

Wantu, FenceM. "Mewujudkan Kepastian Hukum, Keadilan dan Kemanfaatan dalam Putusan Hakim di Peradilan Perdata." Jurnal Dinamika Hukum 12, no. 3 (2012).

Zuni Ayu Pratiwi. "Analisis Yuridis Terhadap Isbat Nikah Karena Pernikahan Sirri oleh Wali Muhakkam dalam Penetapan Pengadilan Agama Bangkalan No. 720/Pdt.P/2017/PA.Bkl." Skripsi, UIN Sunan Ampel, 2018. 